Nicholas, D. J. D., Fisher, D. J., Redmond, W. J. \& Wright, M. A. (1960). J. gen. Microbiol. 22, 191-205

\title{
Some Aspects of Hydrogenase Activity and Nitrogen Fixation in Azotobacter spp and in Clostridium pasteurianum
}

\author{
By D. J. D. NICHOLAS, D. J. FISHER, W. J. REDMOND AND \\ M. A. WRIGHT \\ A.R.C. Unit of Plant Nutrition (Micronutrients), Long Ashton \\ Research Station, University of Bristol
}

SUMMARY: Hydrogenases from Azotobacter vinelandii and Clostridium pasteurianum reduced methylene blue, ferricyanide, benzyl- and methyl-viologens when hydrogen was the donor. Methylene blue was the most effective acceptor. Hughes press preparations of either organism in tris (2-amino-2-hydroxymethyl propane-1:3-diol) buffer (pH 8.0) resulted in the best extraction of the enzyme. Hydrogenase from C. pasteurianum was readily inactivated by traces of oxygen but this could be prevented by sodium dithionite. Pyridine nucleotides and cytochrome $c$. are reduced by hydrogenase, but in extracts of Azotobacter, however, the addition of iron was required to couple DPNH to cytochrome $c$. The mechanism appears to involve the reduction of $\mathrm{Fe}^{\mathrm{s}+}$ to $\mathrm{Fe}^{2+}$ enzymically and the $\mathrm{Fe}^{2+}$ is oxidized by cytochrome $c$ non-enzymically. The effect of $\mathrm{pH}$ value and nature of buffer on this system was examined. $\mathrm{Mo}^{5+}$ did not reduce cytochrome $c$, with or without hydrogenase.

Metal-deficiency experiments, inhibitor studies, activation of dialysed preparations, and the results of radioactive tracer assays of purified protein fractions, showed that iron is the main metal constituent of hydrogenase. Molybdenum, however, is required for the fixation of nitrogen.

Since the work of Bortels (1930) it has been known that molybdenum is required for nitrogen fixation in Azotobacter species, and that vanadium can partially replace it in this process. Horner, Burk, Allison \& Sherman (1942), Esposito \& Wilson (1955), Nicholas (1957) and Bové, Bové \& Arnon (1957) confirmed that molybdenum is essential when Azotobacter is utilizing atmospheric nitrogen, although its replacement by vanadium may vary with species. Takahashi \& Nason (1957) and Keeler \& Varner (1957) showed that tungstate is a competitive inhibitor of molybdate in nitrogen fixation, and Keeler \& Varner $(1957 a)$ demonstrated the incorporation of tungstate into the same protein fraction as molybdenum. Esposito \& Wilson (1955) showed that calcium and iron were also required for nitrogen fixation in Azotobacter vinelandii and Nicholas $(1957,1958 a, b)$ showed that a deficiency of iron or molybdenum restricted the fixation of nitrogen in Azotobacter and in Clostridium.

The enzyme hydrogenase of a range of micro-organisms, which reversibly activates hydrogen gas (Stephenson \& Stickland, 1933) was shown by Lee \& Wilson (1943) to be correlated with nitrogen-fixing capacity in Azotobacter; organisms grown with combined nitrogen contained significantly less hydrogenase than those which were utilizing gaseous nitrogen only. Hoch, Little \& Burris (1957) identified a hydrogen exchange reaction in root-nodule bacteria 
(Rhizobium). Hydrogenase is, however, present in bacteria which do not fix nitrogen, e.g. Escherichia coli. Hydrogenase is also associated with the terminal component of the system responsible for the photochemical formation of hydrogen and for the evolution of this gas in the fermentation of carbohydrates, amino acids, purines and related substances. Shug, Wilson, Green \& Mahler (1954) and Shug, Hamilton \& Wilson (1956) suggested that hydrogenase from Clostridium pasteurianum is a flavoprotein enzyme dependent on molybdenum, whereas Peck \& Gest (1957) showed that in Clostridium butylicum the enzyme is primarily an iron-containing flavoprotein. In the present paper some effects of trace metals on nitrogen fixation and hydrogenase activity in various Azotobacter species and in Clostridium pasteurianum are presented.

\section{METHODS}

Organisms. Azotobacter vinelandii $(0)$ and Clostridium pasteurianum W-S were kindly supplied by Dr P. W. Wilson, Wisconsin University, Madison, U.S.A. A. chroococcum 8003 was obtained from the National Collection of Industrial Bacteria, Teddington, London.

Culture media. The bacteria were grown in the following media (g./l./ deionized water): for Azotobacter chroococcum; sucrose, 10; $\mathbf{K H}_{2} \mathbf{P O}_{4}, \mathbf{1}$; $\mathrm{MgSO}_{4} .7 \mathrm{H}_{2} \mathrm{O}, 0 \cdot 2 ; \mathrm{Na}$ acetate, $0 \cdot 2 ; \mathrm{Ca}$ citrate, $0 \cdot 2 ; \mathrm{NaCl}, 0 \cdot 1 ; \mathrm{FeSO}_{4} .7 \mathrm{H}_{2} \mathrm{O}$, $0.01 ; \mathrm{Na}_{2} \mathrm{MoO}_{4} .2 \mathrm{H}_{2} \mathrm{O}, 0.001$; adjusted to $\mathrm{pH} \mathrm{7.5}$; for Azotobacter vinelandii (O); sucrose, $50 ; \mathrm{KH}_{2} \mathrm{PO}_{4}, 0 \cdot 1 ; \mathrm{MgSO}_{4} .7 \mathrm{H}_{2} \mathrm{O}, 0 \cdot 4 ; \mathrm{Na}$ citrate, $0.2 ;$ Ca acetate, $0.2 ; \mathrm{NaCl}, 0.1 ; \mathrm{FeSO}_{4} .7 \mathrm{H}_{2} \mathrm{O}, 0.01 ; \mathrm{Na}_{2} \mathrm{MoO}_{4} .2 \mathrm{H}_{2} \mathrm{O}, 0.001$; for Clostridium pasteurianum; sucrose, 20 ; malic acid, $0.5 ; \mathrm{KH}_{2} \mathrm{PO}_{4}, 0.5 ; \mathrm{K}_{2} \mathrm{HPO}_{4}, 0.5$; $\mathrm{MgSO}_{4} .7 \mathrm{H}_{2} \mathrm{O}, 0.2 ; \mathrm{NaCl}, 0 \cdot 1 ; \mathrm{CaCO}_{3}, 5 ; \mathrm{FeSO}_{4} .7 \mathrm{H}_{2} \mathrm{O}, 0.01 ; \mathrm{MnSO}_{4} .4 \mathrm{H}_{2} \mathrm{O}$, $0.01 ; \mathrm{Na}_{2} \mathrm{MoO}_{4} \cdot 2 \mathrm{H}_{2} \mathrm{O}, 0.001$. The water used for solution was deionized in a Permutit Deminrolit Mark IV plant.

Removal of trace metals from culture media. Methods described previously (Nicholas, 1952) were used to remove Mo and Fe from a solution of macronutrient constituents of the media. The phosphates were purified and autoclaved separately and when cold were added to the rest of the sterilized medium. This procedure prevented the precipitation which usually occurs when phosphates are autoclaved with the other constituents of the medium. The trace metals, spectrographically tested for purity, were supplied by Johnson Matthey (Hatton Garden, London, E.C.1.) The purified culture solutions were adjusted to $\mathrm{pH} 7.3$ with $5 \%(\mathrm{w} / \mathrm{v})$ sodium hydroxide which had been passed through a well-washed Amberlite (IRA-400) anion exchange column $(20$ in. $\times 3$ in.) to remove molybdate. The Mo content of the solution after passage through the resin was $<0.001 \mu \mathrm{g} . / \mathrm{ml}$. as determined by bioassay (Nicholas, 1952).

Growth of organisms. All strains of Azotobacter, maintained on nutrient agar slopes at $25^{\circ}$, were subcultured every 6 days. The media for slopes consisted of (g./1. deionized water): 1, yeast extract; 2, peptone; 20, sucrose; I, $\mathrm{KH}_{2} \mathrm{PO}_{4} ; 0.2, \mathrm{MgSO}_{4} .7 \mathrm{H}_{2} \mathrm{O} ; 0.2, \mathrm{CaAc} ; 0.003, \mathrm{FeCl}_{3} .6 \mathrm{H}_{2} \mathrm{O} ; 0.005$, $\mathrm{Na}_{2} \mathrm{MoO}_{4} \cdot 2 \mathrm{H}_{2} \mathrm{O} ; 25$, agar; adjusted to $\mathrm{pH} \mathrm{7 \cdot 5}$. Inocula for large-scale experi- 
ments were prepared in 11 . of appropriate culture medium. Cultures of Azotobacter vinelandii $(0)$ were well aerated with sterile air dispersed in the media by passage through sintered-glass disks.

Inoculum of Clostridium pasteurianum for large-scale experiments was grown under semi-anaerobic conditions in $4 \mathrm{oz}$. medicine bottles fitted with screw caps containing $100 \mathrm{ml}$. of the following medium (g./l. deionized water): 20, glucose; 1 tryptone (Difco); 1 , agar, $1, \mathrm{CaCO}_{3}$.

For large-scale experiments the bacteria were grown in 10 l. Pyrex jars each containing $8 \mathrm{l}$. medium. The Azotobacter spp. were grown for $48 \mathrm{hr}$. at $30^{\circ}$ and Clostridium pasteurianum for $48 \mathrm{hr}$. at $37^{\circ}$. Cultures of $A$. vinelandii (0) were well aerated with sterile air. Nitrogen gas was passed through cultures of $C$. pasteurianum to maintain anaerobic conditions. The bacteria, collected in the cold in a Sharples centrifuge at $30,000 \mathrm{~g}$, were washed twice in $0.85 \%(\mathrm{w} / \mathrm{v}) \mathrm{NaCl}$ solution and stored in a deep-freeze cabinet at $-17^{\circ}$.

Preparation of cell-free extracts. Washed organisms were disrupted in a Hughes press (1951) at $-30^{\circ}$. Azotobacter vinelandii $(0)$ organisms, suspended in 0.2 M-tris (2-amino-2 hydroxymethyl-propane-1: 3-diol) buffer ( $\mathrm{pH} \mathrm{8.0)}$ at $8 \mathrm{~g}$. wet wt. organism $/ 24 \mathrm{ml}$. buffer, were put in the press precooled to $-\mathbf{2 0}^{\circ}$ with solid carbon dioxide. The frozen suspension of organisms was disrupted by dropping a steel weight $(112 \mathrm{lb}$.) on to the press plunger in a special pile-driver. Clostridium pasteurianum was suspended in $0 \cdot 1 \mathrm{M}$-phosphate buffer ( $\mathrm{pH} \mathrm{7.5)}$ and treated in the same way. The crushed material was collected in a plastic tube and after thawing was centrifuged at $20,000 \mathrm{~g}$ for $30 \mathrm{~min}$. (unless otherwise stated). The supernatant solution, which was used in some experiments as a source of hydrogenase, was also fractionated by conventional methods.

Assay of hydrogenase. Hydrogen uptake by whole organisms and their extracts was measured in a Warburg apparatus, with a variety of $\mathrm{H}$-acceptors including benzyl and methyl-viologen, methylene blue, and potassium ferricyanide. The routine assay with methylene blue was as follows. Main compartment: $1 \mathrm{ml}$. 0.2 M-phosphate buffer ( $\mathrm{pH} \mathrm{7.5}$ ); $0.5 \mathrm{ml} .10^{-2} \mathrm{M}-\mathrm{Na}_{2} \mathrm{~S}_{2} \mathrm{O}_{4}$ in $0.1 \mathrm{M}-$ phosphate $(\mathrm{pH} \mathrm{7.5}) ; 0.5 \mathrm{ml} .8 \%$ (w/v) gelatin; $0.5 \mathrm{ml}$. enzyme preparation. Side-arm: $0.5 \mathrm{ml} .3 \times 10^{-2} \mathrm{M}$-methylene blue. Centre well: $0.2 \mathrm{ml} .20 \%(\mathrm{w} / \mathrm{v})$ KOH. Gas phase hydrogen; bath temperature $33^{\circ}$. The addition of $15 \mu$ mole sodium dithionite stabilized the hydrogenase and gelatin protected it from inhibition by the various dye acceptors. The specific activity of the enzyme is expressed in $\mu \mathrm{l}$. $\mathrm{H}_{2} / \mathrm{mg}$. $\mathrm{N}$ or protein $/ \mathrm{hr}$. i.e. $\mathrm{QH}_{2}$ (acceptor).

Total nitrogen and protein determinations. Total nitrogen was determined in whole organisms and in extracts by the micro-Kjeldahl method. Protein was determined in extracts by the Folin method of Lowry, Rosebrough, Farr \& Randall (1951). Enzyme extracts prepared in tris buffer and those fractionated with ammonium sulphate were thoroughly dialysed against running tap water for $24 \mathrm{hr}$. before protein or nitrogen determinations. Growth determinations were based on turbidity measurements and the total $\mathbf{N}$ content of centrifuged deposits from cultures.

Cofactors and other compounds. Diphosphopyridine nucleotide (DPN) and 
triphosphopyridine nucleotide (TPN), both $98 \%$ pure, and cytochrome $c$ (95\% pure) were obtained from Sigma Chemical Company, U.S.A. Reduced DPN was enzymically prepared by the alcohol dehydrogenase method of Pullman, Colowick \& Kaplan (1954). Crystalline alcohol dehydrogenase was prepared by Racker's method (1955) from Acorn yeast (Distillers Company, Ltd., Bristol). TPN was reduced by the isocitric acid dehydrogenase enzyme prepared from acetone powder of pig heart.

\section{RESULTS}

\section{Hydrogenase in whole organisms and in extracts}

The effects of various acceptors on hydrogenase activity in whole cells of Azotobacter vinelandii $(0)$ and Clostridium pasteurianum are shown in Table 1. The concentraton of each acceptor was that required for maximum hydrogen uptake. The specific activity of the enzyme in C. pasteurianum was considerably greater than in $A$. vinelandii (O). Methylene blue was the most effective acceptor, especially in the Clostridium. Enzyme activity in both organisms was

\section{Table 1. Effect of various $H$-acceptors on hydrogenase activity in whole} Azotobacter vinelandii $(O)$ and Clostridium pasteurianum

Warburg assay. Main compartment: 1 ml. 0.2 M-phosphate (pH 7.5); 0.5 ml. 10-2 ${ }^{-}-\mathrm{Na}_{2} \mathrm{~S}_{2} \mathrm{O}_{4}$ in $0.1 \mathrm{M}$-phosphate (pH 7.5);0.5 ml. $8 \%(\mathrm{w} / \mathrm{v})$ gelatin; $0.5 \mathrm{ml}$. suspension washed organism (Azotobacter equiv. $1.06 \mathrm{mg}$. N/ml.; Clostridium equiv. $2.08 \mathrm{mg}$. N/ml.). Sidearm: $0.5 \mathrm{ml}$. acceptor at concentration indicated. Centre well : 0.2 ml. $20 \%$ KOH. Gas phase hydrogen; bath temperature $\mathbf{3 3}^{\circ}$.

\begin{tabular}{|c|c|c|c|c|c|}
\hline \multirow[b]{2}{*}{ Acceptor } & \multirow[b]{2}{*}{$\begin{array}{c}\text { Molar } \\
\text { concentration }\end{array}$} & \multicolumn{2}{|c|}{ A. vinelandii } & \multicolumn{2}{|c|}{ C. pasteurianum } \\
\hline & & $\begin{array}{l}\text { Without } \\
\text { dithionite }\end{array}$ & $\begin{array}{c}\text { With } \\
\text { dithionite }\end{array}$ & $\begin{array}{l}\text { Without } \\
\text { dithionite }\end{array}$ & $\begin{array}{c}\text { With } \\
\text { dithionite }\end{array}$ \\
\hline & & \multicolumn{4}{|c|}{$\mathbf{H}_{\mathbf{2}}$ uptake $(\mu \mathrm{l} . / \mathrm{mg}: \mathrm{N} / \mathrm{hr}$.) } \\
\hline Methylene blue & $3 \times 10^{-2}$ & 6,700 & 9,400 & $\mathbf{3 6 , 6 0 0}$ & 58,600 \\
\hline Potassium ferricyanide & $3 \times 10^{-1}$ & 4,750 & $\mathbf{5 , 3 5 0}$ & 9,100 & 22,400 \\
\hline Benzyl viologen & $8 \times 10^{-2}$ & 50 & 50 & $\mathbf{3 , 0 0 0}$ & 4,200 \\
\hline Methyl viologen & $3 \times 10^{-2}$ & 10 & 10 & 1,700 & 2,000 \\
\hline
\end{tabular}

much decreased when benzyl- or methyl-viologen replaced methylene blue. Traces of oxygen readily inactivated the enzyme in the Clostridium and sodium dithionite stabilized it when methylene blue or ferricyanide were the acceptors.

The amount of enzyme extracted from whole organisms by various methods was similar (as \%) in the two organisms: Hughes press, 98; Mickle disintegrator, 75; alumina grinding or ultrasonic treatment, 60 . The effect of suspending the bacteria in buffers before the Hughes press treatment is shown in Table 2. Maximum extraction of the hydrogenase after centrifuging at $23,000 \mathrm{~g}$ was achieved in both organisms with 0.2 $\mathrm{M}$-tris buffer ( $\mathrm{pH} \mathrm{8.0)}$. The relative effectiveness of four acceptors for measuring enzyme activity in extracts was similar to that obtained with whole organisms.

Although it was not possible to detect an uptake of hydrogen in a Warburg apparatus with extracts of either organism when using cytochrome $c$ or 


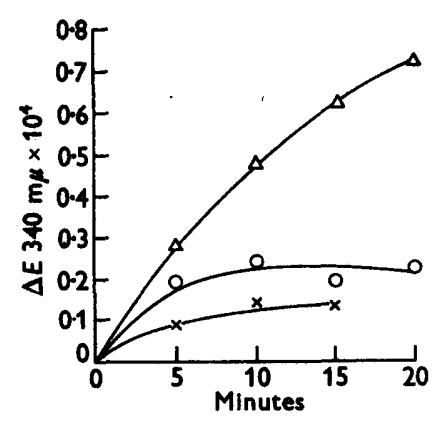

Fig. 1

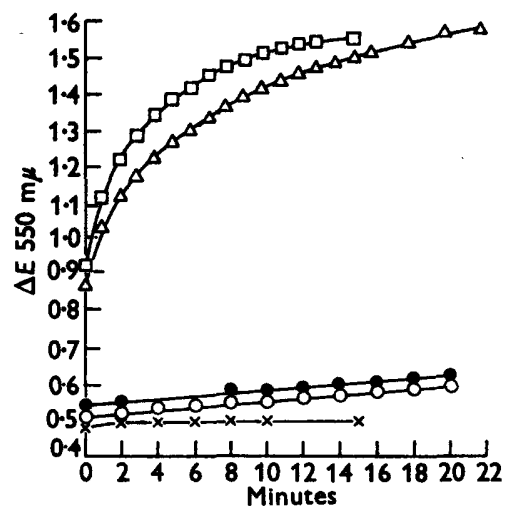

Fig. 2

Fig. 1. Reduction of DPN and TPN by hydrogenase extracted in $0 \cdot 1 \mathrm{M}-$ phosphate (pH 7.5) from Clostridium pasteurianum W-S measured at $840 \mathrm{~m} \mu$. Extracts prepared in a Hughes press and centrifuged at $20,000 \mathrm{~g}$ and supernatant solution used. Reaction mixture ( $8 \mathrm{ml}$.) in a special Thunberg tube with a silica cuvette attachment, contained 0.2 mmole phosphate buffer (pH 7.5), 0.1 ml. extract. Sidesrm: $4 \mu$ mole DPN or TPN. Thunberg tube evacuated and filled with $\mathrm{H}_{2}$ (free from $\mathrm{O}_{2}$ ). $\Delta-\Delta=\mathrm{DPN}+$ enzyme; $\mathrm{O}-\mathrm{O}=\mathrm{DPN}+$ boiled enzyme; $\mathrm{x}-\mathrm{x}=\mathrm{TPN}$ +enzyme.

Fig. 2. Enzymic reduction of cytochrome $c$ by hydrogenase in a phosphate extract of Clostridium pasteurianum W-S measured at $550 \mathrm{~m} \mu$. Extracts prepared in a Hughes press and centrifuged at $20,000 \mathrm{~g}$ and supernatant solution used. Reaction mixture $(8 \mathrm{ml}$.) in $1 \mathrm{~cm}$. cuvette fitted to a Thunberg tube contained $0.2 \mathrm{mmole}$ phosphate (pH 7.5), 0.1 ml. extract, $8 \mu$ mole KCN. Sidearm: 0.1 $\mu$ mole cytochrome $c$. Thunberg tube evacuated and filled with $\mathrm{H}_{2}$ (free from $\mathrm{O}_{2}$ ) or He. $\square-\square=$ enzyme $+\mathrm{KCN}$ $\left(\mathrm{H}_{2}\right) ; \triangle-\triangle=$ enzyme $\left(\mathrm{H}_{2}\right) ; \bigcirc$, enzyme (He); $\mathrm{O}-\mathrm{O}=$ enzyme $+\mathrm{KCN}$ (He); $x-x=$ boiled enzyme $\left(H_{2}\right.$ or $\left.\mathrm{He}\right)$.

\section{Table 2. Hydrogenase activity of whole organisms and Hughes press extracts} of Azotobacter vinelandii $(O)$ and of Clostridium pasteurianum

Warburg assay. Main compartment: $1 \mathrm{ml}$. 0.2 M-phosphate (pH 7.5); $0.5 \mathrm{ml} .1^{-2} \mathrm{M}-$ $\mathrm{Na}_{2} \mathrm{~S}_{2} \mathrm{O}_{4}$ in 0.1 M-phosphate $(\mathrm{pH} \mathrm{7.5}) ; 0.5 \mathrm{ml} .8 \%$ (w/v) gelatin $; 0.5 \mathrm{ml}$. suspension of washed organisms, homogenate, particles or supernatant solution. (Azotobacter, washed suspension, equiv. $1.9 \mathrm{mg}$. $\mathrm{N} / \mathrm{ml}$; supernatant solution, equiv. $2 \mathrm{mg} . \mathrm{N} / \mathrm{ml}$. Clostridium, washed suspension equiv. $2.08 \mathrm{mg}$. $\mathrm{N} / \mathrm{ml}$; ; supernatant solution, equiv. $1 \mathrm{mg}$. $\mathrm{N} / \mathrm{ml}$.) Sidearm: $0.5 \mathrm{ml} .8 \times 10^{-2} \mathrm{M}-$ methylene blue. Centre well : $0.2 \mathrm{ml} .20 \% \mathrm{w} / \mathrm{v} \mathrm{KOH}$. Gas phase hydrogen; bath temperature $33^{\circ}$.

\begin{tabular}{|c|c|c|c|c|c|}
\hline & & $\mathbf{Q H}_{\mathbf{2 ( \mathbf { H B } )}} / \mathrm{ml} . / \mathrm{h}$ & & & \\
\hline Extractant & $\begin{array}{c}\text { Whole } \\
\text { organisms }\end{array}$ & Homogenate & $\begin{array}{l}\text { Supernatant } \\
\text { solution } \\
\text { after } \\
\text { centrifuging } \\
\text { at } 23,000 \mathbf{g} \\
\text { for } 1 \mathrm{hr} \text {. }\end{array}$ & $\begin{array}{c}\text { Particles } \\
\text { after } \\
\text { centrifuging } \\
\text { at } 23,000 \mathrm{~g}\end{array}$ & $\begin{array}{c}\% \\
\text { extracted } \\
\text { in super- } \\
\text { natant } \\
\text { solution }\end{array}$ \\
\hline $\begin{array}{l}\text { A. vinelandii (O) } \\
\text { 0.1 M-phosphate } \\
\text { (pH } 7 \cdot 5 \text { ) }\end{array}$ & 85,900 & 10,900 & $\mathbf{8 , 0 0 0}$ & 22,000 & $\mathbf{2 8}$ \\
\hline $0 \cdot 2 \mathrm{M}$-tris (pH 8.0) & $\mathbf{8 5 , 9 0 0}$ & 16,200 & 10,400 & 1,000 & 63 \\
\hline C. pasteurianum W-S & & & & & \\
\hline $\begin{array}{l}0.1 \mathrm{~m}-\text { phosphate } \\
(\text { pH } 7 \cdot 5)\end{array}$ & 278,000 & 480,000 & 288,000 & 210,000 & 60 \\
\hline $0.2 \mathrm{~m}$-tris (pH 8.0) & 276,000 & 652,000 & 669,000 & 8,300 & 100 \\
\hline & & & & & $13-2$ \\
\hline
\end{tabular}


pyridine nucleotides as acceptors, the results in Figs. 1 and 2 show that extracts of the Clostridium reduced cytochrome $c$ or DPN (but not TPN) in the presence of hydrogen. The reduction of cytochrome $c$ by hydrogenase from Azotobacter has already been reported (Hyndman, Burris \& Wilson, 1953). Extracts of Azotobacter reduced cytochrome $c$ when DPNH was the electrondonor, provided that ferric iron was added (Fig. 3). In this system DPNH reduced $\mathrm{Fe}^{3+}$ to $\mathrm{Fe}^{2+}$ enzymically as measured by the formation of the ferrous o-phenanthroline complex (Fig. 4) and $\mathrm{Fe}^{2+}$ is known to reduce cytochrome $c$ non-enzymically (Webber, Lenhoff \& Kaplan, 1956). The latter reaction, however, is markedly affected by the $\mathrm{pH}$ value and the composition of buffer

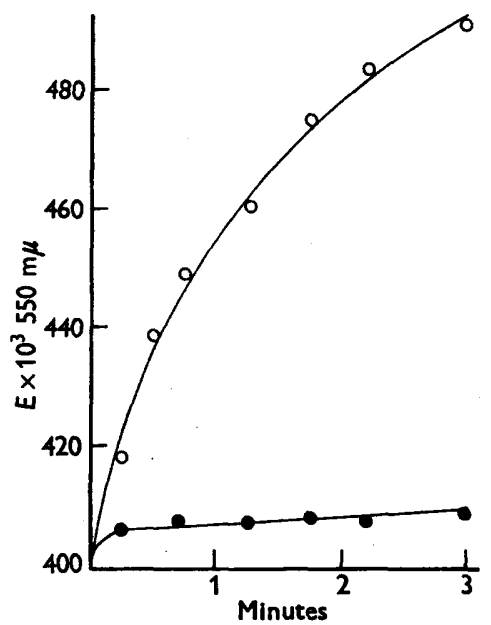

Fig. 3

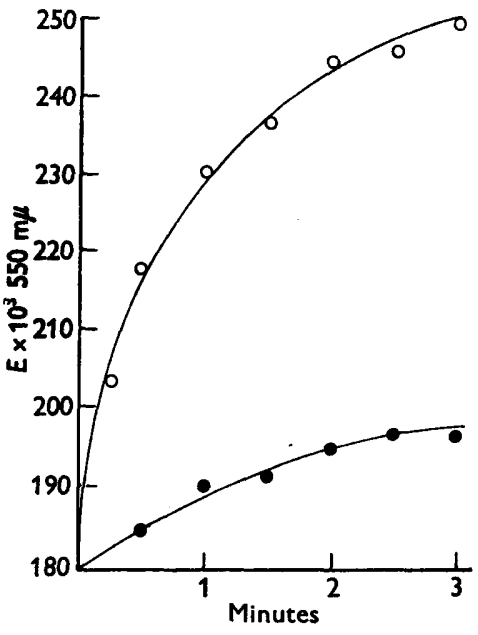

Fig. 4

Fig. 3. Enzymic reduction of cytochrome $c$ by DPNH measured at $550 \mathrm{~m} \mu$ in $1 \mathrm{~cm}$. optical cells, in a crude extract of Azotobacter vinelandii $(O)$ in the presence of ferric chloride. Cuvette contained: 0.2 mmole phosphate (pH 6.8), $0.1 \mu$ mole cytochrome $c ; 0.1 \mathrm{ml}$. extract, $0 \cdot 1 \mu$ mole DPNH. This gave endogenous rate; then $1 \mu$ mole ferric chloride added. $\mathrm{O}-\mathrm{O}=$ enzyme; $-\mathrm{O}=$ boiled enzyme.

Fig. 4. Enzymic reduction of ferric chloride by DPNH in a crude extract of Azotobacter vinelandii $(\mathrm{O})$ in presence of $o$-phenanthroline. Ferrous $o$-phenanthroline complex measured at $550 \mathrm{~m} \mu$ in $1 \mathrm{~cm}$. optical cell. Cuvette contained: 0.20 mmole phosphate buffer (pH 6.5); 0.1 ml. enzyme; $0.1 \mu$ mole DPNH; 0.2 $\mu$ mole o-phenanthroline; no endogenous rate; then $0 \cdot 1 \mu$ mole ferric chloride added. $\mathrm{O}-\mathrm{O}=$ enzyme; $-0=$ boiled enzyme.

used (Figs. 5-7). The effect of different valency states of Mo on the reduction of cytochrome $c$ was studied with and without hydrogenase; only $\mathbf{M o}^{3+}$ reduced it chemically. $\mathrm{Mo}^{5+}$ was without effect, with or without the enzyme. Thus in Azotobacter hydrogen is linked enzymically to cytochrome $c$, and Fe but not Mo is required in this system. 


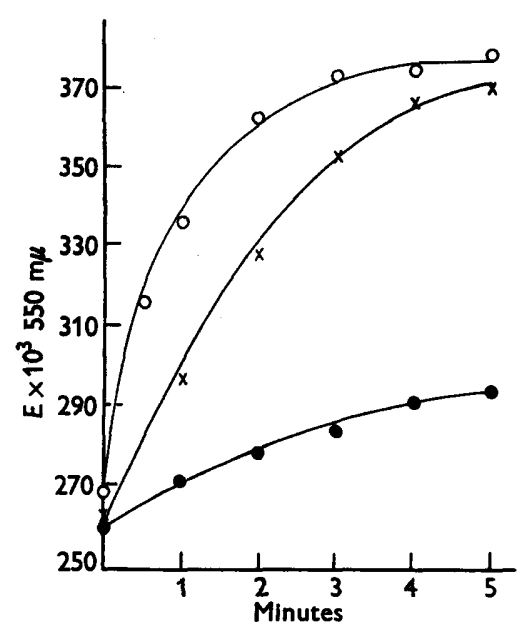

Fig. 5

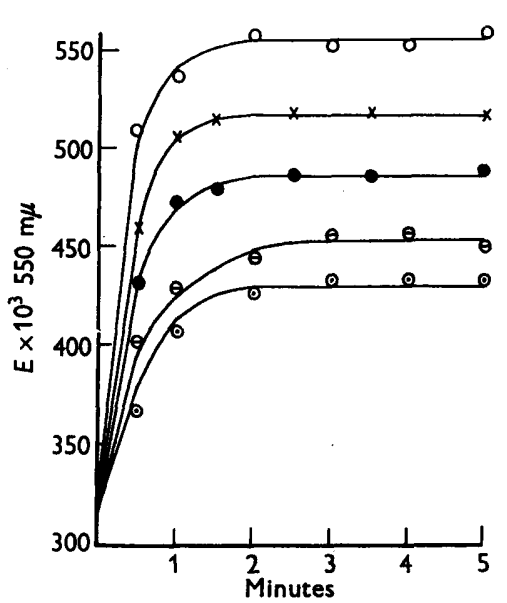

Fig. 6

Fig. 5. Chemical reduction of cytochrome $c$ by ferrous sulphate in phosphate buffer measured at $550 \mathrm{~m} \mu$ in $1 \mathrm{~cm}$. optical cells at: $\mathrm{pH} 5$. - $-\mathrm{pH} \mathrm{6,} \times-x ; \mathrm{pH} \mathrm{7,O-O}$. Cuvette contained : $0 \cdot 20$ mmole phosphate; $0 \cdot 1 \mu$ mole cytochrome $c ; 0 \cdot 1 \mu$ mole ferrous sulphate.

Fig. 6. Chemical reduction of cytochrome $c$ by ferrous sulphate in acetate buffer measured at $550 \mathrm{~m} \mu$ in $1 \mathrm{~cm}$. optical cell. At pH 3, $\odot-\odot ;$ pH 4, $\odot-\ominus ;$ pH 5, - ; pH 6, $x-x$; pH 7, $O-O$; Cuvette contained : $0 \cdot 20$ mmole acetate; $0 \cdot 1 \mu$ mole cytochrome $c$; $0 \cdot 1 \mu$ mole ferrous sulphate.

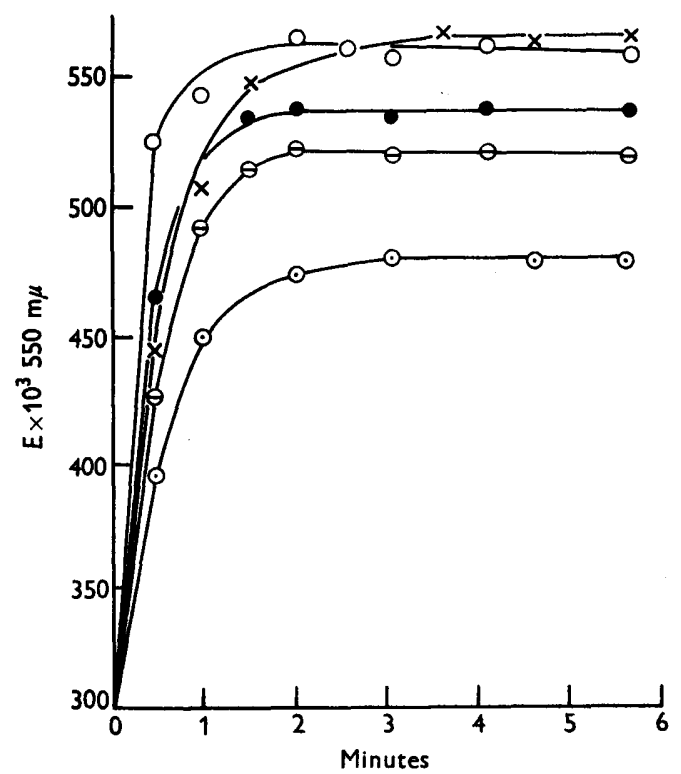

Fig. 7 . Chemical reduction of cytochrome $c$ by ferrous sulphate in citrate buffer measured at $550 \mathrm{~m} \mu$ in1 cm. optical cell. At pH 3, $\odot-\odot ;$ pH 4, - ; pH 5, $\times-\times$; pH 6, $\ominus-\ominus$; pH $7, O-O$. Cuvette contained : 0.20 mmole sodium citrate; $0.1 \mu$ mole cytochrome $c$; $0 \cdot 1 \mu$ mole ferrous sulphate. 
Effects of trace metals on nitrogen fixation and hydrogenase

A molybdenum requirement for growth of Azotobacter chroococcum 8003 is shown in Fig. 8, the optimum requirement being $0.01 \mu \mathrm{g}$. Mo/ml. The organisms had a wide tolerance for the metal; it did not become toxic until $0 \cdot 1 \mathrm{mg}$. $\mathrm{Mo} / \mathrm{ml}$. was reached. Iron was required in greater amounts than Mo as illustrated (Fig. 9). Sodium vanadate replaced molybdate in the growth of A. chroococcum to the extent of $70 \%$ (Fig. 10).

The effects of deficiencies of $\mathrm{Fe}$ and Mo on nitrogen-fixation and hydro-

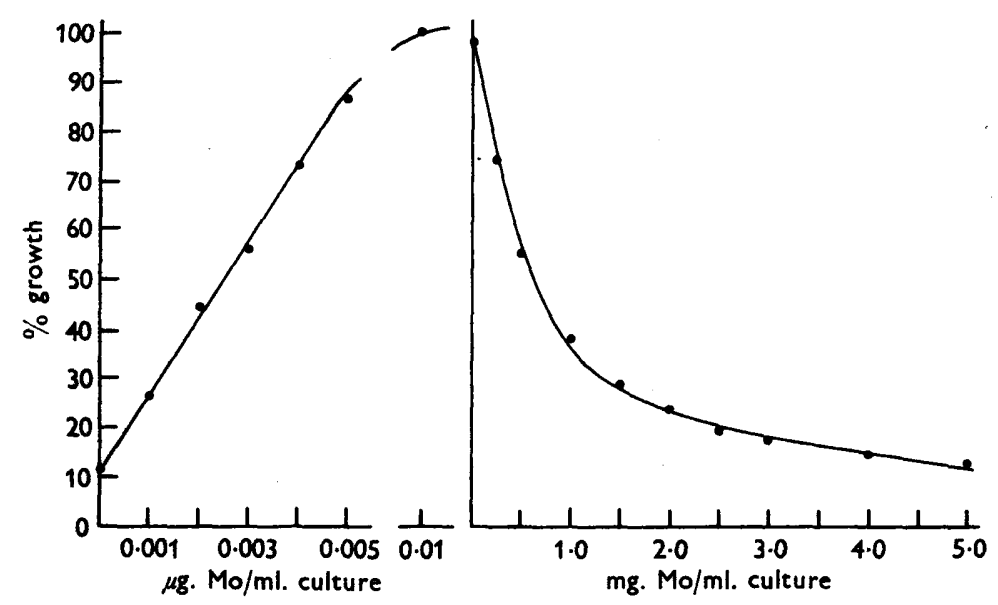

Fig. 8. Effect of Mo content of culture medium on the growth of Azotobacter chroococcum 8003. Abscissa : \% growth based on turbidity measurements. Ordinate: $\mu \mathrm{g}$. or mg. Mo/ml. medium.
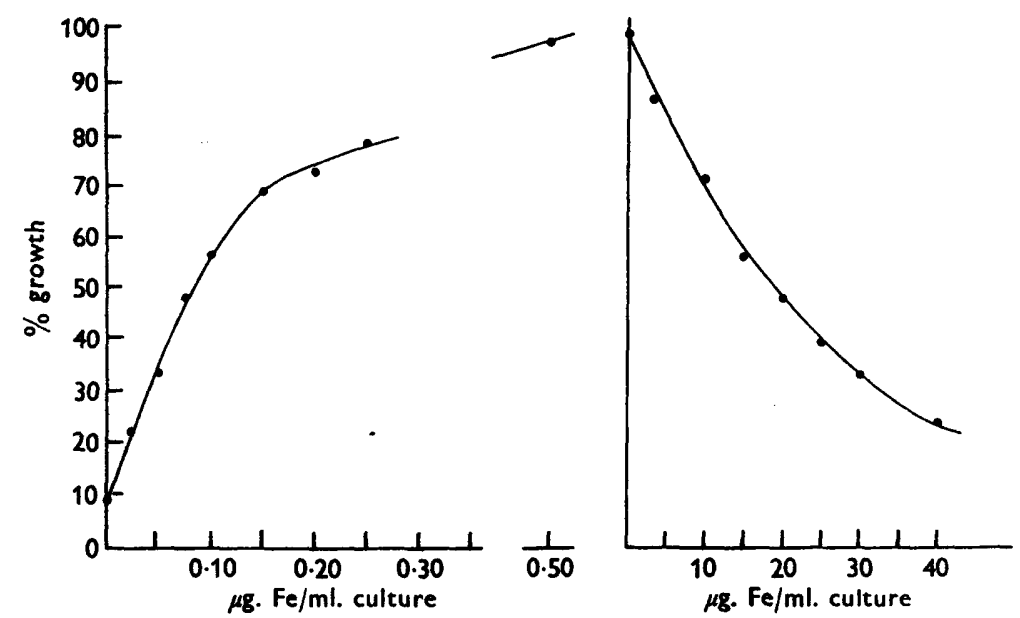

Fig. 9. Effect of Fe content of culture medium on the growth of Azotobacter chroococcum 8003. Abscissa : $\%$ growth based on turbidity measurements. Ordinate : $\mu \mathrm{g}$. Fe/ml. medium. 


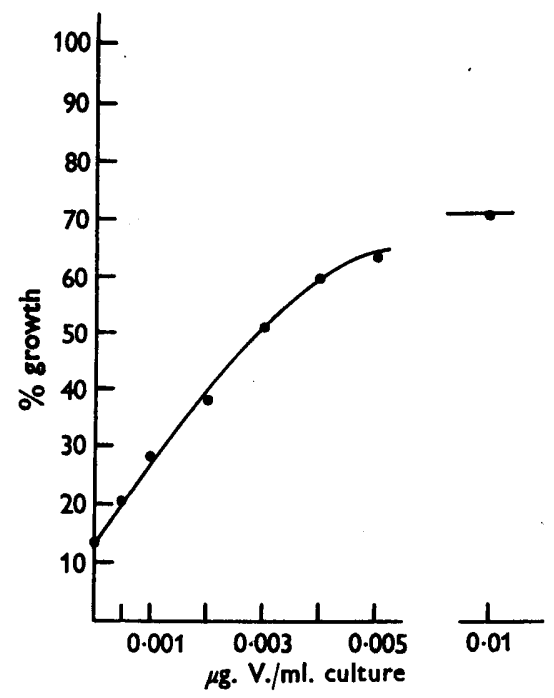

Fig. 10. Effect of sodium vanadate in replacing sodium molybdate for the growth of Azotobacter chroococcum 8003.

genase activity in Azotobacter vinelandii $(0)$ and Clostridium pasteurianum are illustrated in Table B. A deficiency of $\mathrm{Fe}$ in both organisms markedly decreased hydrogenase activity, but Mo deficiency had no effect on the Azotobacter enzyme and only a small effect on the Clostridium enzyme. Both metals, however, were required for nitrogen fixation; a shortage of Mo had the most profound effect since it was independent of yield of organism.

Table 8. Hydrogenase activity and nitrogen fixation in Azotobacter vinelandii $(O)$ and Clostridium pasteurianum $W-S$

Methylene blue was used as H-acceptor for assay of hydrogenase.

\begin{tabular}{|c|c|c|c|c|c|c|}
\hline Organism & Azoto & bacter vine & landii & Clostri & um paste & ianum \\
\hline Nutrient solution & $\begin{array}{c}\text { Full } \\
\text { culture }\end{array}$ & $\underset{\text { omitted }}{\text { Fe }}$ & $\begin{array}{l}\text { Mo } \\
\text { omitted }\end{array}$ & $\begin{array}{c}\text { Full } \\
\text { culture }\end{array}$ & $\begin{array}{c}\text { Fe } \\
\text { omitted }\end{array}$ & $\begin{array}{c}\text { Mo } \\
\text { omitted }\end{array}$ \\
\hline $\begin{array}{l}\text { Hydrogenase } Q_{\mathrm{H}_{2}}(\mathrm{MB}) / \\
\mathrm{mg} \cdot \mathrm{N} / \mathrm{hr} \text {. in whole } \\
\text { organism }\end{array}$ & 4,620 & 1,150 & 4,150 & 58,400 & 16,200 & 48,100 \\
\hline $\begin{array}{l}\text { Total } \mathrm{N}_{\mathbf{8}} \text { fixed mg. } \mathrm{N} / \\
81 . \text { culture }\end{array}$ & 1,000 & 600 & 416 & 670 & 436 & $\mathbf{2 4 0}$ \\
\hline $\begin{array}{l}\text { Dry weight yields } \\
\text { of organism as \% } \\
\text { normal }\end{array}$ & 100 & $\mathbf{3 5}$ & 70 & 100 & 45 & 75 \\
\hline
\end{tabular}

Table 4 shows the effects of sodium tungstate and sodium vanadate on hydrogenase activity and nitrogen-fixation; $2 \times 10^{-3} \mathrm{M}$-tungstate in the medium depressed nitrogen fixation but had no effect on hydrogenase activity. A similar result was obtained when molybdenum was omitted; the addition of 
sodium tungstate to these cultures depressed further the nitrogen fixation but had no effect on hydrogenase. Sodium vanadate at equivalent concentrations to tungstate did not depress nitrogen fixation.

Table 4. Hydrogenase activity and nitrogen fixation in Azotobacter vinelandii $(O)$ and in Clostridium pasteurianum $W-S$

Culture medium

1. Full culture

2. Full culture $+10^{-3} \mathrm{M}$-sodium tungstate

3. Full culture $+2 \times 10^{-8} \mathrm{M}-$ sodium tungstate

4. Molybdenum omitted

5. Molybdenum omitted; sodium tungstate $10^{-8} \mathrm{M}$ added

6. Molybdenum omitted; $2 \times 10^{-8} \mathrm{M}$ sodium vanadate added
Hydrogenase in whole organism $\mathbf{Q H}_{2}$ (MB)/mg $\mathbf{N}$ fixed

$\begin{array}{lllll}8,600 & 108,000 & & 590 & 68 \\ 8,000 & 124,000 & 500 & 56\end{array}$

7,700

84,000

250

$\begin{array}{llll}8,600 & 87,000 & 220 & 24\end{array}$

$\begin{array}{llll}8,600 & 87,000 & 220 & 24\end{array}$

200

8,200

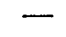

$-\quad 210$

Total N fixed by organism/l. medium

18

7,900

The concentration of hydrogenase from Clostridium pasteurianum

The method described by Shug, Wilson, Green \& Mahler (1954) for purifying hydrogenase from Clostridium was not successful in our hands since the enzyme is irreversibly inactivated by traces of oxygen. Ethanol inactivated the enzyme no matter what precautions were taken to keep the preparations in a reduced state, e.g. by adding sodium dithionite and storing in Thunberg tubes under hydrogen. Dr D. Westlake has recently experienced similar difficulties with this purification (Dr P. W. Wilson, private communication).

A fractionation of hydrogenase from Clostridium pasteurianum is shown in Table 5. The organism was grown in media freed from iron to which was returned $0.75 \mathrm{mg}$. ferric chloride labelled with $0.66 \mu \mathrm{c}{ }^{50} \mathrm{Fe}$ per 1 . The various protein fractions were assayed for radioactivity in a scintillation counter (Nicholas, Lloyd-Jones \& Fisher 1957) and for hydrogenase activity. The results (Fig. 11) show that iron concentrated in the more purified fractions of the enzyme. Molybdenum did not accumulate in these fractions, and the addition of sodium molybdate did not increase the activity of the purified enzyme. Similar results were obtained with hydrogenase from Azotobacter although a good purification of this enzyme was not achieved.

The inhibition of the partially purified enzyme from Azotobacter was very pronounced when it was dialysed at $4^{\circ}$ against $0 \cdot 1 \mathrm{M}$-phosphate buffer $(\mathrm{pH} 7 \cdot 5)$ $+0.01 \mathrm{M}$-sodium dithionite containing $5 \times 10^{-3} \mathrm{M}$. o-phenanthroline. After dialysis for $6 \mathrm{hr}$. the enzyme preparation was transferred to a fresh solution of the same buffer + dithionite and dialysis continued for a further $6 \mathrm{hr}$. by which time excess o-phenanthroline was removed. At this stage reactivation of the enzyme was tried by returning metals (including Fe, Mo) to samples of the dialysed enzyme preparation. The results (Table 6) show that dialysis against 


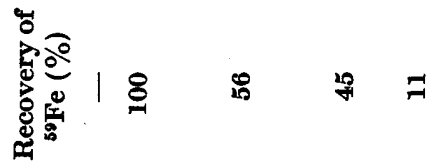

要密

$\&$ สี

है

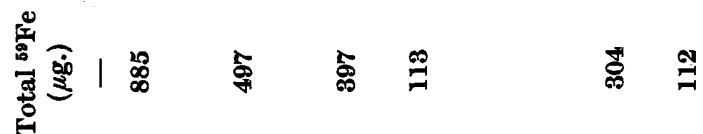

ㅇํㅇ

产 1 \& 8 ส 7 क

造

:

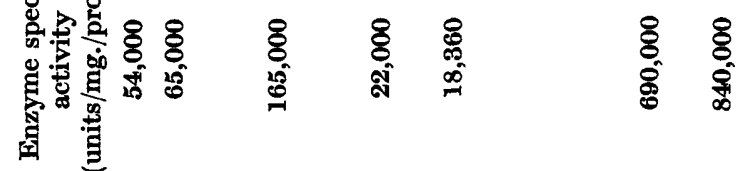

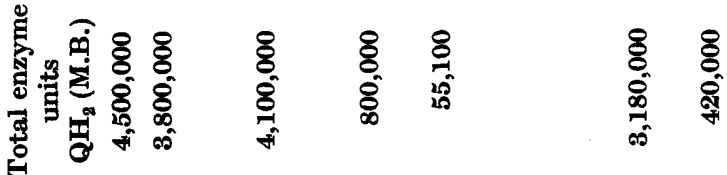

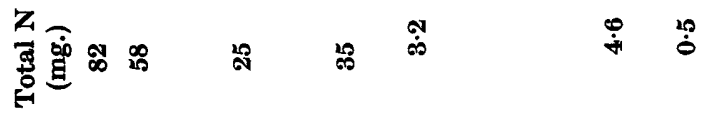

ह1

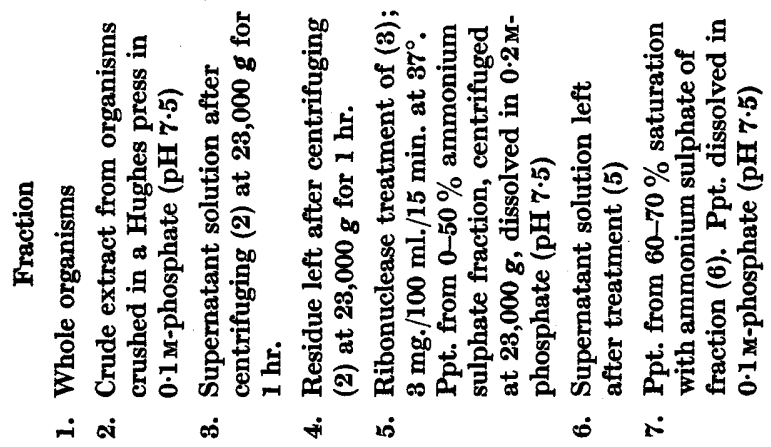


o-phenanthroline markedly decreased enzyme activity. Subsequent dialysis against dithionite in phosphate buffer, however, resulted in a recovery of enzymic activity, presumably because the 0 -phenanthroline was removed from the enzyme, thus indicating that $\mathrm{Fe}^{\mathrm{s}+}$ was held more tightly by the protein than by the chelate. When no further recovery of enzyme activity was observed, and no 0 -phenanthroline could be detected in the preparation, the addition of $\mathrm{Fe}^{2+}$ reactivated the enzyme by $\mathbf{3 5 - 4 3} \%$, whereas the addition of molybdate produced little effect. The addition of $\mathrm{Zn}$, which has a higher affinity for $o$-phenanthroline than has $\mathrm{Fe}^{2+}$, did not stimulate the enzyme.

It was not possible to remove the iron from the Clostridium enzyme preparation by dialysis, although numerous methods were tried. This may mean that iron is very tightly bound in the enzyme.

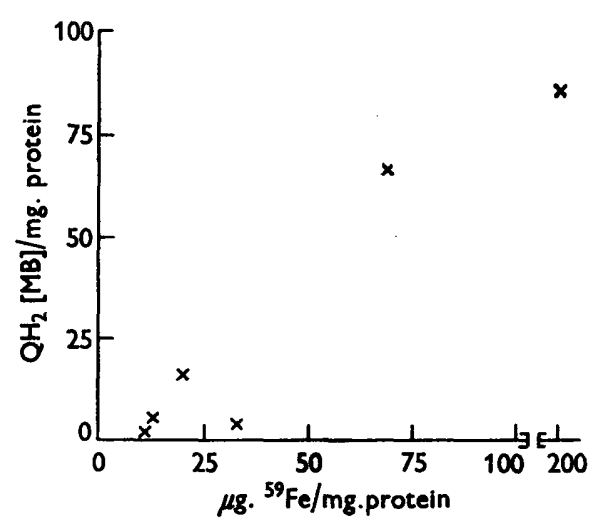

Fig. 11. Relation between the iron content and hydrogenase activity of protein fractions prepared from a Hughes press extract of Clostridium pasteurianum W-S.

\section{DISCUSSION}

Hydrogenase reduces pyridine nucleotides in a number of micro-organisms when hydrogen is the donor (Korkes, 1955; Vishniac \& Ochoa, 1952; Shug \& Wilson, 1954; Peck \& Gest, 1954). Cytochrome $c$ is also a suitable acceptor (Hyndman et al. 1953); Shug, Hamilton \& Wilson, 1956). In the present work these effects have been confirmed and it is also shown that iron is required to couple DPNH to cytochrome $c$ in extracts of Azotobacter vinelandii (0). The mechanism involves the enzymic reduction of $\mathrm{Fe}^{3+}$ to $\mathrm{Fe}^{2+}$ by DPNH and then the reduction of the cytochrome by $\mathrm{Fe}^{2+}$ non-enzymically. The fact that the non-enzymic reduction to $\mathrm{Fe}^{2+}$ is fast at physiological $\mathrm{pH}$ values makes it a likely mechanism for cytochrome reduction in vivo in Azotobacter. Webber, Lenhoff \& Kaplan (1956) showed that $\mathrm{Fe}^{3+}$ was reduced to $\mathrm{Fe}^{2+}$ by flavoproteins in extracts of Pseudomonas fluorescens and that $\mathrm{Fe}^{2+}$ reduced cytochrome $c$ chemically. Although extracts of Clostridium pasteurianum reduce cytochrome $c$ in vitro as effectively as do those from $A$. vinelandii $(O)$ this cannot be the natural system since $C$. pasteurianum is devoid of cytochrome. Thus here the cytochrome acts as would a suitable redox dye $\mathrm{H}$-acceptor and it has 


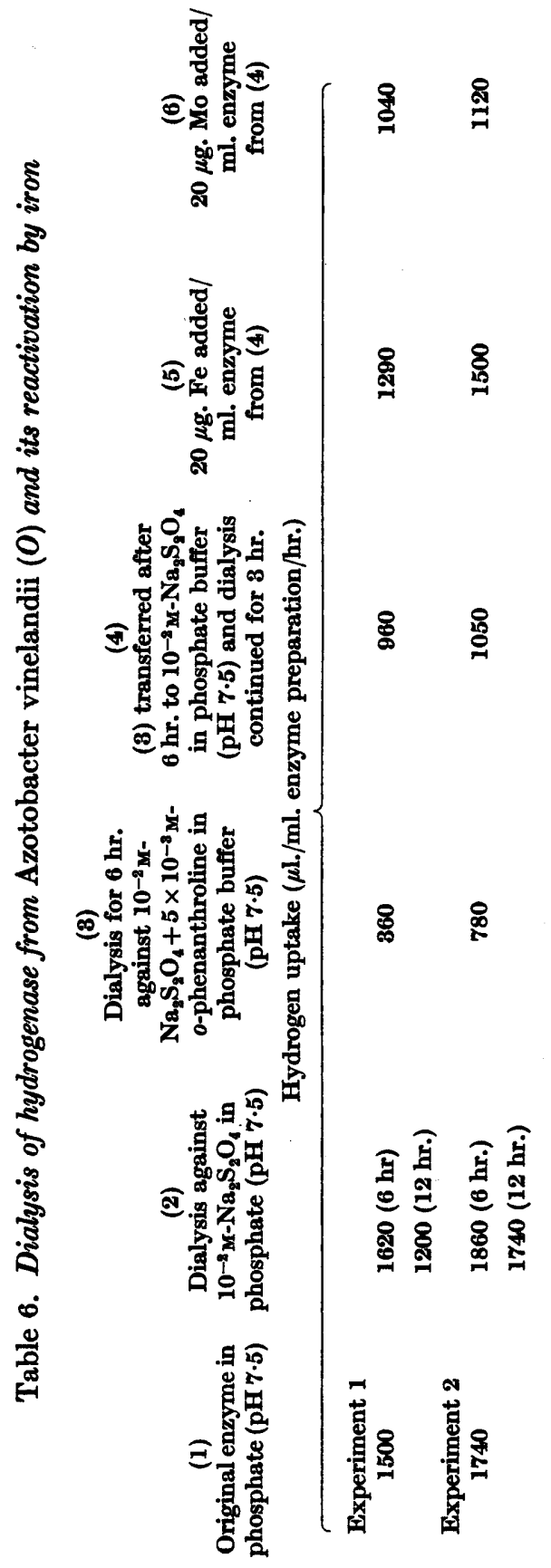


no physiological significance. $\mathrm{Mo}^{6+}$ or $\mathrm{Mo}^{5+}$ cannot replace $\mathrm{Fe}^{2+}$ in this reaction; only $\mathrm{Mo}^{3+}$ reduced cytochrome $c$ non-enzymically. This is of interest since Shug et al. (1954) suggested that Mo is required to couple hydrogen to cytochrome $c$ in hydrogenase from C. pasteurianum. Evidence presented in the present paper however suggests that Fe and not Mo is the main constituent of hydrogenase. This is in accord with the results of Waring \& Werkman (1944) with Aerobacter indologenes, Hoberman \& Rittenberg (1943) with Proteus vulgaris, Peck \& Gest (1957) with C. butylicum and Postgate (1951) and Sadana \& Jagannathan (1956) with Desulfovibrio desulfuricans.

Molybdenum is required for nitrogen fixation and only in Azotobacter chroococcum did vanadium replace it to the extent of $70 \%$. The precise role of Mo in the fixation process must await further work. The metal is probably associated with the enzyme system which activates nitrogen. It has already been shown that Mo is important for nitrogen metabolism since nitrate reduction from micro-organisms requires Mo for its functioning (Nicholas \& Nason, 1954; Nicholas \& Stevens, 1955). The inhibitor and metal deficiency studies reported here have shown hydrogenase and nitrogenase to be distinct enzyme systems.

\section{REFERENCES}

Bortels, H. (1930). Molybdän als Katalysator bei der biologischen Stickstoffbindung. Arch. Mikrobiol. 1, 333.

Bové, J., Bové, C. \& ARnon, D. I. (1957). Molybdenum and vanadium requirements of Azotobacter for growth and nitrogen fixation. Plant Physiol. 32, Suppl. XXIII.

Hoberman, H. D. \& Rittenberg, D. (1943). Biological catalysis of the exchange reaction between water and hydrogen. J. biol. Chem. 147, 211.

Hoch, G. E., LitTle, H. N. \& Burris, R. H. (1957). Hydrogen evolution from soybean root nodules. Nature, Lond. 179, 430.

Horner, C. K., Burk, D., Axlison, F. E. \& Sherman, M. S. (1942). Nitrogen fixation by Azotobacter as influenced by molybdenum and vanadium. $J$. agric. Res. 65, 173.

Hughes, D. (1951). A press for disrupting bacteria and other micro-organisms. Brit. J. exp. Path. 32, 97.

Hyndman, L. A., Burris, R. H. \& Wilson, P. W. (1953). Properties of hydrogenase from Azotobacter vinelandii. J. Bact. 65, 522.

JokLIK, W. K. (1950). The hydrogenase of $\boldsymbol{E}$. coli in the cell-free state. 1. Concentration properties and activation. Aust. J. exp. Biol. med. Sci. 28, 321.

Kreler, R. F. \& VARNER, J. E. (1957). Tungstate as an antagonist of molybdate in Azotobacter vinelandii. Arch. Biochem. Biophys. 70, 585.

Keeler, R. F. \& VARNer, J. E. (1957 $a$ ). A comparison of tungsten and molybdenum incorporation into Azotobacter vinelandii. Bact. Proc. p. 112.

KorKes, S. (1955). Enzymatic reduction of pyridine nucleotides by molecular hydrogen. J. biol. Chem. 216, 737.

LEe, S. \& Wilson, P. W. (1943). Hydrogenase and nitrogen fixation by Azotobacter. J. biol. Chem. 151, 377.

Lowry, O. H., Rosebrough, N. J., Farr, A. L. \& Randall, R. J. (1951). Protein measurement with the Folin phenol reagent. J. biol. Chem. 193, 265.

Nicholas, D. J. D. (1952). The use of fungi for determining trace metals in biological materials. Analyst, 77, 629.

Nicholas, D. J. D. \& Nason, A. (1954). The mechanism of action of nitrate reductase from Neurospora. J. biol. Chem. 211, 183. 
Nicholas, D. J. D. \& Stevens, H. M. (1955). Valency changes of molybdenum during the enzymatic reduction of nitrate. Nature, Lond. 176, 1066.

Nicholas, D. J. D., Lloyd-Jones, C. P. \& Fisher, D. J. (1957). Some problems associated with determining iron in plants. Plant \& Soil, 8, 367.

NichоцAs, D. J. D. (1957). Role of trace metals in the nitrogen metabolism of plants with special reference to micro-organisms. J. Sci. Food Agric. 8 (Suppl. 15.)

Nicholas, D. J. D. (1958a). Some biochemical aspects of nitrogen fixation. In Nutrition of the Legumes, ed. E. G. Hallsworth. London: Butterworths.

NichoLAS, D. J. D. (1958 b). Some effects of trace metals on hydrogenase activity and nitrogen fixation in Azotobacter spp. and in Clostridium pasteurianum. J. appl. Bact. 21, iv.

Oснол, S. (1955). Isocitric dehydrogenease system (TPN) from pig-heart. In Methods in Enzymology, ed. S. P. Colowick \& N. O. Kaplan, vol. I, p. 699. New York: Academic Press Inc.

PeCK, H. \& Gest, H. (1954). Enzymic reduction of pyridine nucleotides by molecular hydrogen. Biochim. biophys. Acta, 15, 587.

Peck, H. \& Gest, H. (1957). Hydrogenase of Clostridium butylicum. J. Bact.73, 569.

Peck, H. San Pietro, A. \& Gest, H. (1956). On the mechanisms of hydrogenase action. Proc. nat. Acad. Sci., Wash. 42, 13.

Postante, J. R. (1951). The reduction of sulphur compounds by Desulfovibrio desulfricans. J. gen. Microbiol. 5, 725.

Pullman, M., Colowick, S. P. \& Kaplan, N. O. (1954). Comparison of diphosphopyridine nucleotide with its deaminated derivative in various enzyme systems. J. biol. Chem. 194, 593.

RACKER, E. (1955). Alcohol dehydrogenase from baker's yeast. In Methods in Enzymology, ed. S. P. Colowick \& N. O. Kaplan, vol. I, p. 500. New York: Academic Press Inc.

Sadana, J. C. \& Jagannathan, V. (1956). Purification and properties of the hydrogenase of Desulfovibrio desulfuricans. Biochim. biophys. Acta, 19, 440.

Shug, A. \& Wirson, P. W. (1954). The hydrogenase of Azotobacter vinelandii. Bact. Proc. p. 111.

Shug, A., Wilson, P. W., Green, D. E. \& Mahler, H. R. (1954). The role of molybdenum and flavin in hydrogenase. J. Amer. chem. Soc. 76, 3355.

Shug, A., Hamilton, P. B. \& Wirson, P. W. (1956). Hydrogenase and nitrogen fixation. In Symposium on Inorganic Nitrogen Metabolism, ed. W. D. McElroy, \& B. H. Glass, p. 844. Baltimore: Johns Hopkins Press.

Stephenson, M. \& Strickland, L. H. (1933). Hydrogenlyases. III. Further experiments on the formation of formic hydrogenlyase by Bacterium coli. Biochem. $J$. $27,1528$.

TAkaHAShi, H. \& Nason, A. (1957). Tungstate as a competitive inhibitor of molybdate in $\mathrm{N}_{2}$ fixation by Azotobacter. Biochim. biophys. Acta, 23, 433.

Vishniac, W. \& OchoA, S. (1952). Reduction of pyridine nucleotides in photosynthesis. In Phosphorus Metabolism, ed. W. D. McElroy \& B. H. Glass, vol. 2, p. 467. Baltimore: Johns Hopkins Press.

Waring, W. S. \& Werkman, C. H. (1944). Iron deficiency in bacterial metabolism. Arch. Biochem. 4, 75.

Webber, M. W., Lenhoff, H. M. \& Kaplan, N. O. (1956). The reduction of inorganic iron and cytochrome $c$ by flavin enzymes. J. biol. Chem. 220, 93.

Wrison, P. W. (1958). Asymbiotic nitrogen fixation. Handb. PflPhysiol. 8, 9. Berlin: Springer-Verlag.

(Received 14 February 1959) 